\title{
Observations on the incidence and cause of anaemia in ulcerative colitis
}

\author{
T. P. ORMEROD
}

From the Department of Medicine, Westminster Hospital, London

EDITORIAL COMMENT These studies confirm the view that there is an iron-deficiency state in ulcerative colitis and that this overshadows the influence of infection as a factor causing anaemia.

The frequency of anaemia has been well established in the many reported series of patients with ulcerative colitis yet the aetiology of the anaemia is still not fully known. The purpose of this study is first to discover whether low haemoglobin levels are associated with any special features in the case reports of 479 patients (group A) and secondly to investigate an additional 28 ward patients (group B) to ascertain the parts played by iron deficiency, shortening of the red cell life, and lack of vitamin $\mathrm{B}_{12}$ or folic acid.

\section{METHODS}

GROUP A The series consisted of a review of the case notes of all in-patients admitted to the Gordon Hospital, London, between January 1950 and October 1963 inclusive because of symptoms due to ulcerative colitis and in whom there was either radiological or histological evidence that the disease had spread beyond the rectum. The following groups of patients were excluded: (1) proctitis only; (2) previous surgical treatment for colitis; (3) carcinoma of colon on admission or developing within the next two years; (4) 21 patients shown in Table I. All live patients are still being followed up; all patients were over 14 years of age on admission apart from two girls aged 10 and 11 years.

The diagnosis was made clinically and confirmed by barium enema and/or histological examination (Dawson

\section{TABLE I}

EXCLUSIONS

No. of Patients

No record of haemoglobin value 10

Previous transfusions of an unknown amount of blood within one month before admission

Additional thyrotoxicosis

No symptoms on admission

Full records not obtainable

No evidence of extent of disease

Total and Pryse-Davies, 1959). Haematological and other values relate to those within 24 hours of the patient's first admission to this hospital with colitis; subsequent admissions are not included. Some patients had previously been admitted to other hospitals. Ten patients had received previous blood transfusions within one month of admission; it is assumed that one pint $(540 \mathrm{ml}$.) raises the haemoglobin by $1 \mathrm{~g} . \%$, so an appropriate subtraction from the haemoglobin value on admission was therefore made in these cases. The majority did not receive haematinics before admission and owing to lack of data this factor has been disregarded.

Haemoglobin was compared with (1) anatomical area of colon involvement seen on barium enema or after total colectomy; (2) mean corpuscular haemoglobin concentration (M.C.H.C.); (3) white blood count and erythrocyte sedimentation rate (E.S.R.); (4) length of history; (5) 'liver function tests', namely, serum alkaline phosphatase, bilirubin, blood urea, total serum proteins and serum albumin levels; (6) patient's age; and (7) year of admission to hospital.

GROUP B All but no. 23 and the last six represented consecutive admissions to the medical unit of the Gordon Hospital. All patients were in an initial attack or a relapse of colitis; none were in remission and none of the female cases had menorrhagia. Further details are given in Table $\mathrm{V}$ and the following investigations were carried out:

Serum iron The method of Marrack (Delaney, 1960) was used.

Serum total iron-binding capacity (T.I.B.C.) The method of Peters, Giovanniello, Apt, and Ross (1956) was used.

Radiochromium $\left({ }^{51} \mathrm{Cr}\right.$ ) studies Labelling of red cells with ${ }^{51} \mathrm{Cr}$ and estimation of their life span was according to the method of Mollison and Veall (1955) except that no corrections were made for elution. Blood loss was measured by the method of Cameron (1960) except that infra-red lamps were used for drying an aliquot of faecal homogenate.

Serum $B_{12}$ and folate levels These were estimated using Euglena gracilis and Lactobacillus casei respectively. 
RESULTS

GROUP A PATIENTS Table II shows that the greater the extent of colon involvement, the greater is the degree of anaemia; many of the apparent differences are statistically highly significant.

TABLE II

HAEMOGLOBIN LEVELS AND THE EXTENT OF COLITIS

\begin{tabular}{cll} 
Extent $\quad$ No. of Cases & $\begin{array}{l}\text { Mean } \\
\text { Haemoglobin } \\
\text { Concentration } \\
(\mathrm{g} . \%)\end{array}$ & Error of Mean \\
& & \\
\hline
\end{tabular}

\begin{tabular}{|c|c|c|c|}
\hline Males & & & \\
\hline $\begin{array}{ll}\text { Total } & \overline{\mathbf{X}}_{1} \\
\text { Partial } & \overline{\mathbf{X}}_{2} \\
\text { Sigmoid } & \overline{\mathbf{X}}_{3}\end{array}$ & $\begin{array}{r}129 \\
53 \\
26\end{array}$ & $\begin{array}{l}11 \cdot 68 \\
12 \cdot 71 \\
13 \cdot 60\end{array}$ & $\begin{array}{l} \pm 0.21 \\
\pm 0.29 \\
\pm 0.46\end{array}$ \\
\hline $\begin{array}{ll}\text { Females } & \\
\text { Total } & \bar{Y}_{1} \\
\text { Partial } & \bar{Y}_{2} \\
\text { Sigmoid } & \bar{Y}_{3}\end{array}$ & $\begin{array}{r}151 \\
88 \\
32\end{array}$ & $\begin{array}{l}10 \cdot 55 \\
11 \cdot 78 \\
11 \cdot 67\end{array}$ & $\begin{array}{l} \pm 0.16 \\
\pm 0.22 \\
\pm 0.33\end{array}$ \\
\hline $\begin{array}{l}\text { Tests of signi } \\
\overline{\mathbf{X}}_{1}-\overline{\mathbf{X}}_{2} \\
\overline{\mathbf{X}}_{2}-\overline{\mathbf{X}}_{3} \\
\overline{\mathbf{Y}}_{1}-\overline{\mathbf{Y}}_{3} \\
\overline{\mathbf{Y}}_{2}-\overline{\mathbf{Y}}_{3}\end{array}$ & $\begin{aligned} \text { cance } & \\
t & =9 \cdot 196 \\
t & =1.642 \\
t & =9.655 \\
t & =0.873\end{aligned}$ & $\begin{array}{l}\mathrm{P}<0.001 \\
\mathrm{P}>0.10<0.20 \\
\mathrm{P}<0.301 \\
\text { Not sig. at } 5 \% \text { level }\end{array}$ & \\
\hline
\end{tabular}

One hundred and twelve females and 83 males had the M.C.H.C. estimated and a highly significant statistical correlation was found between a fall in haemoglobin $(\mathrm{Hb})$ and $a$ fall in M.C.H.C. $(r=+0.51 \mathrm{P}<0.001$ for females and $\mathrm{r}=+0.67$ $\mathrm{P}<0.001$ for males). There was a regression line combined for both sexes of $\mathrm{Hb}=0.550$, M.C.H.C. $=$ 5.95 .

There was no correlation between haemoglobin concentration and white count or E.S.R. (Table III), nor did the haemoglobin level appear to bear any relation to the duration of the disease since first symptoms (Table IV) or to the length and severity of the acute exacerbation leading to admission (Fig. 1). Apart from a significant fall in haemoglobin concentration with lowered serum albumin levels in males, there was also no correlation between the degree of anaemia and the 'liver function tests' (Table III) or the patient's age (Fig. 2).

\section{TABLE IV}

DURATION OF DISEASE SINCE FIRST SYMPTOMS (WHOLE COLON INVOLVED)

\begin{tabular}{|c|c|c|c|c|}
\hline \multirow[b]{2}{*}{$\begin{array}{l}\text { Duration } \\
(y r .)\end{array}$} & \multicolumn{2}{|l|}{ Males } & \multicolumn{2}{|l|}{ Females } \\
\hline & No. of Cases & $\begin{array}{l}\text { Mean } \\
\text { Hb (g.\%) }\end{array}$ & No. of Cases & $\begin{array}{l}\text { Mean } \\
H b(g . \%)\end{array}$ \\
\hline$<1$ & 25 & $12 \cdot 2$ & 26 & $10 \cdot 3$ \\
\hline$>1$ & 14 & $11 \cdot 8$ & 19 & 10.4 \\
\hline$>2$ & 13 & $10 \cdot 6$ & 19 & $10 \cdot 4$ \\
\hline$>3$ & 14 & $10 \cdot 8$ & 10 & $11 \cdot 6$ \\
\hline$>4$ & 4 & $13 \cdot 5$ & 10 & 10.9 \\
\hline$>5$ & 18 & $11 \cdot 8$ & 6 & $11 \cdot 4$ \\
\hline 6 to 9 & 20 & $12 \cdot 8$ & 27 & $10 \cdot 3$ \\
\hline 10 and over & 21 & $11 \cdot 0$ & 34 & $10 \cdot 6$ \\
\hline Total & 129 & $11 \cdot 7$ & 151 & $10 \cdot 5$ \\
\hline
\end{tabular}

Although this series was based on hospital admissions over several years, it was found that over this period the haemoglobin levels of patients admitted did not change significantly.

GROUP B PATIENTS Eight out of nine men and 11 out of 15 women had subnormal serum iron levels (Table V) and it was noted that in men the factor lowering serum iron appeared to be the severity and extent of the inflammation whereas in women lower levels were seen below middle age, regardless of the degree of colitis or the time of the menstrual cycle.

TABLE III

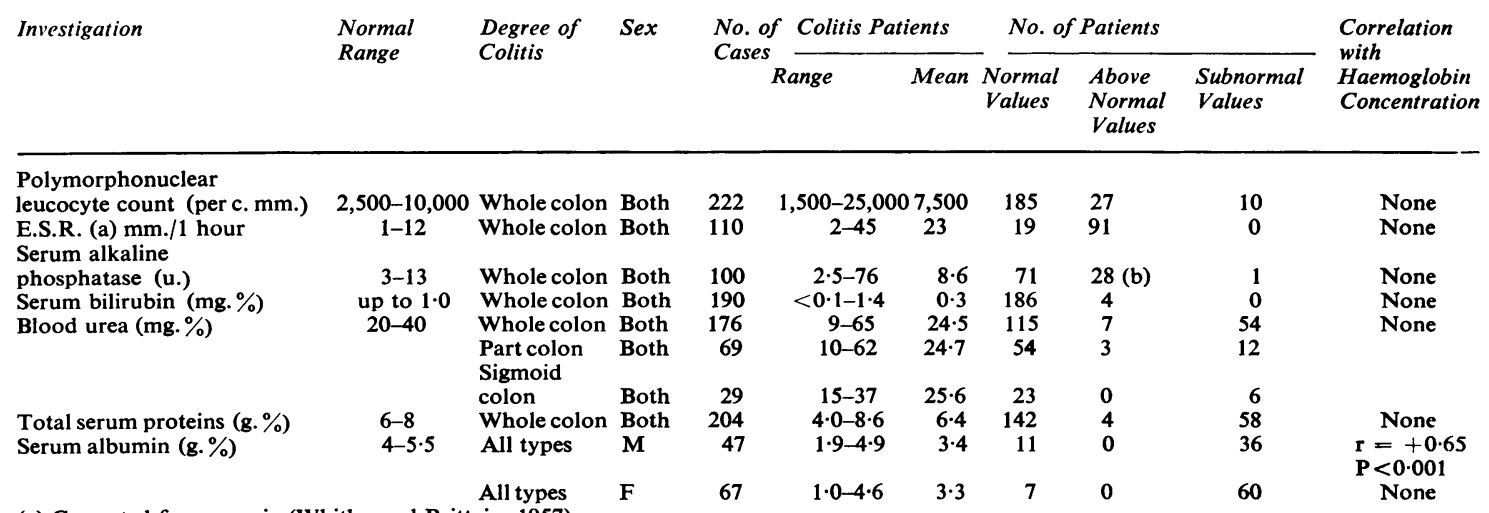

(a) Corrected for anaemia (Whitby and Brittain, 1957). (b) 10 patients had values over $30 u$. 


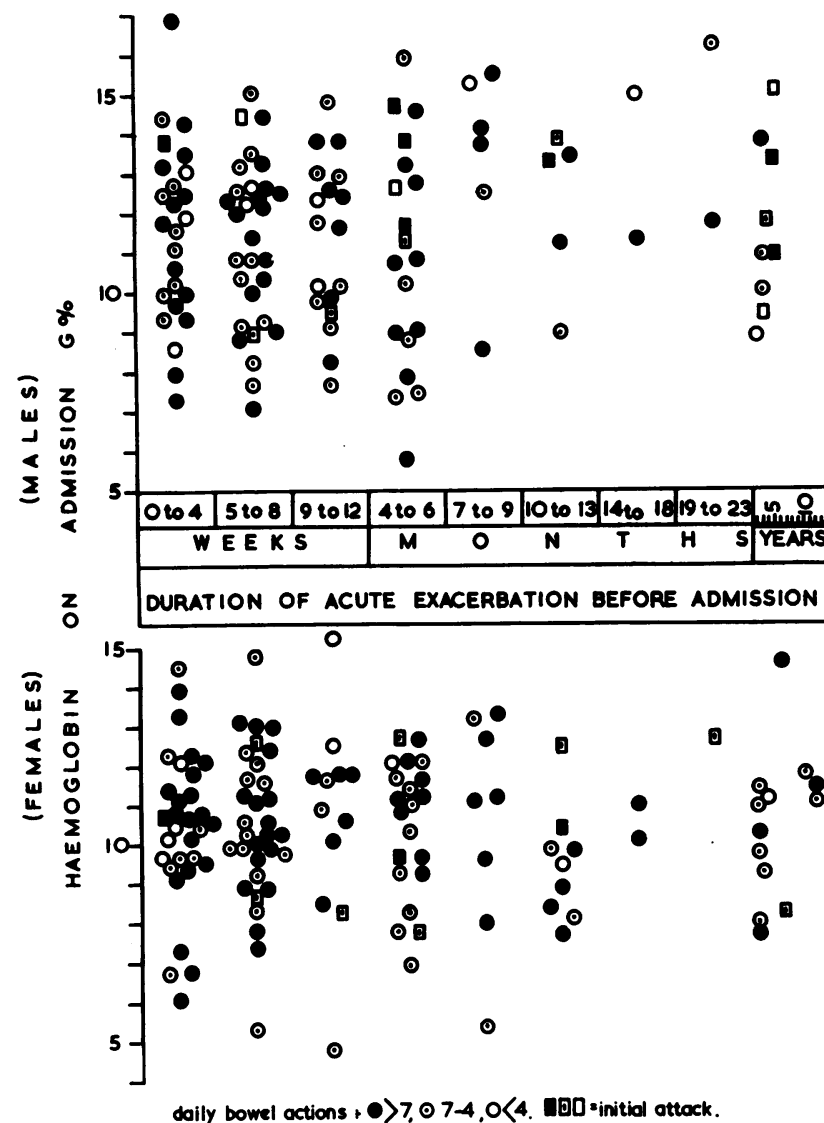

FIG. 1. Haemoglobin concentration compared with duration and severity of acute exacerbation leading to admission to hospital (whole colon involved).

FIG. 2. Haemoglobin level compared with patient's age (whole colon involved).

FIG. 1

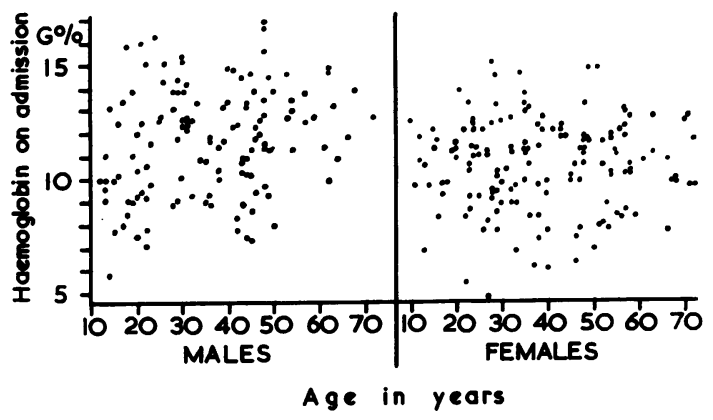

FIG. 2

The T.I.B.C. results were all within the normal range. Table VI shows ${ }^{51} \mathrm{Cr}$ survival in four patients. In two whose colitis symptoms were improving, the half-time was normal, but in another two cases there was considerable shortening of ${ }^{51} \mathrm{Cr}$ half-time.
Serum $B_{12}$ levels were all normal, but of 14 patients in whom the serum folate was estimated, one showed a subnormal concentration, while in three other patients the levels were also rather low (Table V).

\section{DISCUSSION}

It is well known that anaemia is a frequent complication of ulcerative colitis and Table VII shows the degree of anaemia reported in other series. Too great a comparison is not possible owing to the different type of case treated in the various centres. In addition, when sexes are combined, a greater percentage of females (as occurs in this country) tends to give lower average haemoglobin levels when compared, for example, with series from the United States where the sex ratio is more equal.

It is a common clinical impression that patients with the whole colon involved by inflammation are iller in every way and it is thus not surprising that a greater degree of anaemia occurred in such 
TABLE V

CLINICAL DETAILS OF PATIENTS AND HAEMATOLOGICAL FINDINGS

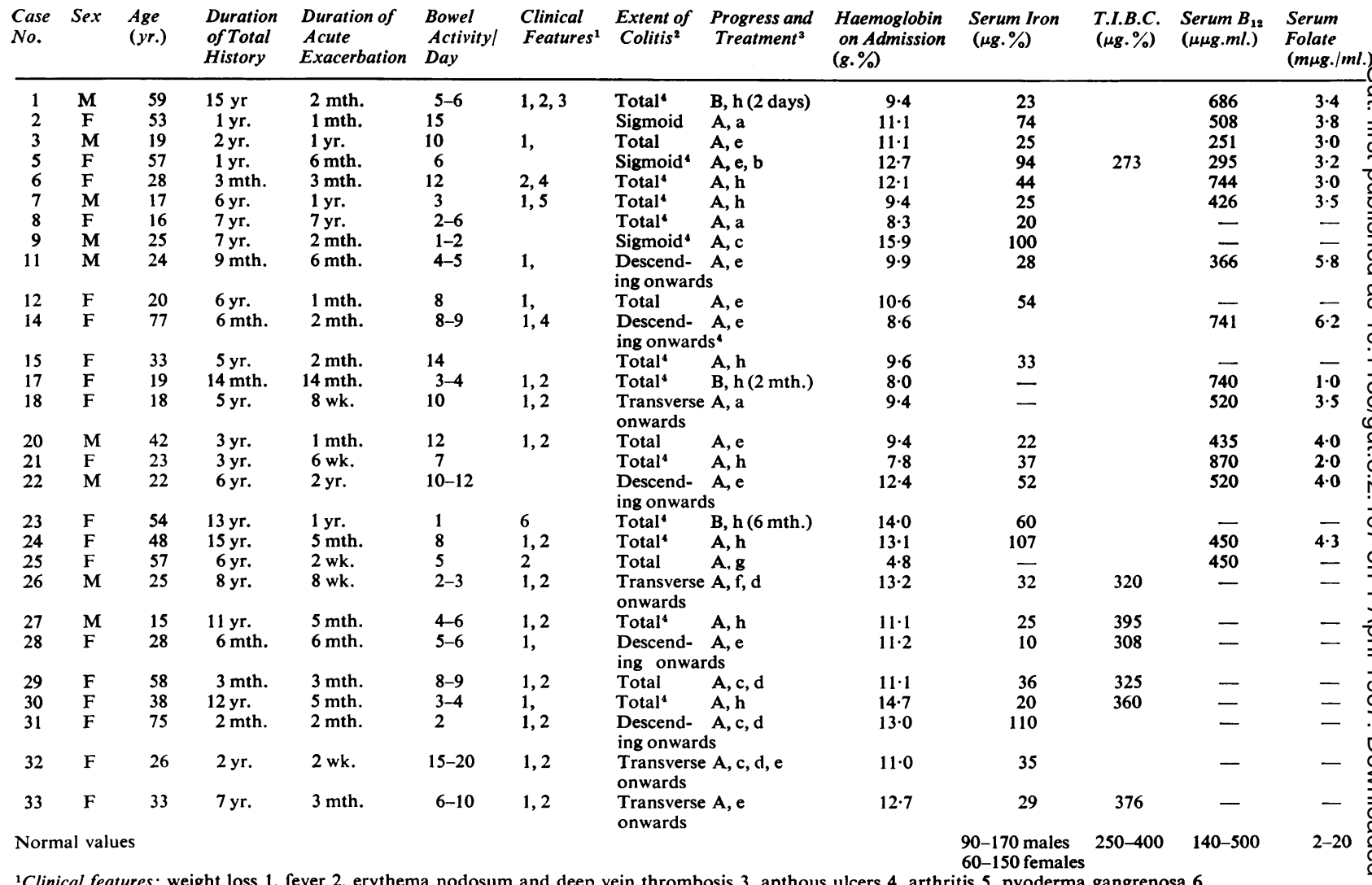

${ }^{1}$ Clinical features: weight loss 1 , fever 2, erythema nodosum and deep vein thrombosis 3, apthous ulcers 4, arthritis 5 , pyoderma gangrenosa 6

${ }^{2} \mathrm{~F}=$ fulminant, destroyed muscle

${ }^{3}$ Progress: improved A, died B. Treatment: codeine phosphate a, phthalysulphathiazole b, salazopyrine c, predsol enemas d, oral prednisolone e, A.C.T.H. splenectomy $\mathrm{g}$, total colectomy and ileorectal anastomosis $\mathrm{h}$.

${ }^{4}$ Biopsy performed.

TABLE VI

SURVIVAL OF RED CELLS TAGGED WITH ${ }^{51}$ CR

\begin{tabular}{ccc} 
Case No. & $T \frac{1}{2}{ }^{51} \mathrm{Cr}($ days $)$ & $\begin{array}{l}T_{\frac{1}{2}}{ }^{51} \text { Cr (days) } \\
\text { Corrected for Blood Loss } \\
\text { (Hughes Jones } \\
\text { Correction) }\end{array}$ \\
\hline 25 & $6 \cdot 5$ & 6.5 \\
15 & $7 \cdot 0$ & $7 \cdot 2$ \\
18 & 26.1 & 28.0 \\
11 & 28.0 & 28.4
\end{tabular}

TABLE VII

INCIDENCE OF ANAEMIA IN OTHER SERIES

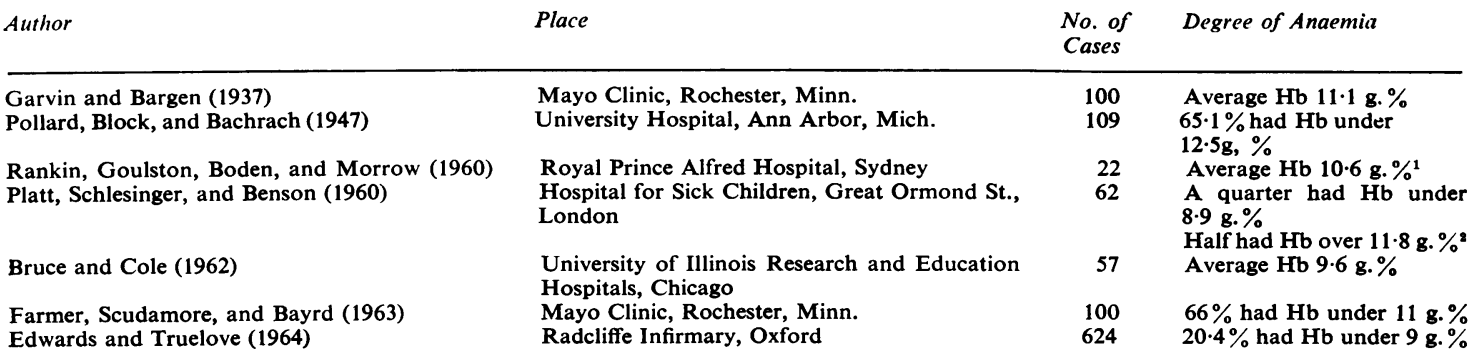

${ }^{1}$ All fulminant cases. ${ }^{2}$ All children. 
patients. Pollard, Block, and Bachrach (1947) also made this observation, but the statistical significance of their results was not given and other studies have not taken the anatomical extent of colitis into account.

Figure 3 shows that anaemic patients tend to have a lowered M.C.H.C. and indeed hypochromia has been described widely in ulcerative colitis (Garvin and Bargen, 1937; Kirsner, Palmer, Maimon, and Ricketts, 1948; Edwards and Truelove, 1964) but a normochromic anaemia may occur after recent haemorrhage and rarely macrocytosis has been reported, usually associated with liver disease (Farmer, Scudamore, and Bayrd, 1963). Unfortunately the M.C.H.C. appears to be of doubtful value in assessing the aetiology of the anaemia because the finding of hypochromia does not necessarily mean that the patient has a total body iron deficiency correctable by iron therapy. In infections, for example, Cartwright and Wintrobe (1952) suggest that the low haemoglobin content of the red cell is due to a block in haem synthesis.

Similar data for the M.C.H.C. and haemoglobin in pure iron deficiency (Beutler, 1959), cancer (Miller, Chodos, Emerson, and Ross, 1956), and rheumatoid arthritis (Freireich, Ross, Bayles, Emerson, and Finch, 1957) are shown in Figure 3. Although the slope of the regression line for ulcerative colitis resembles that of rheumatoid arthritis rather than iron deficiency, there is such a wide scatter of M.C.H.C. values that a close comparison is probably not possible.

Although Edwards and Truelove reported that

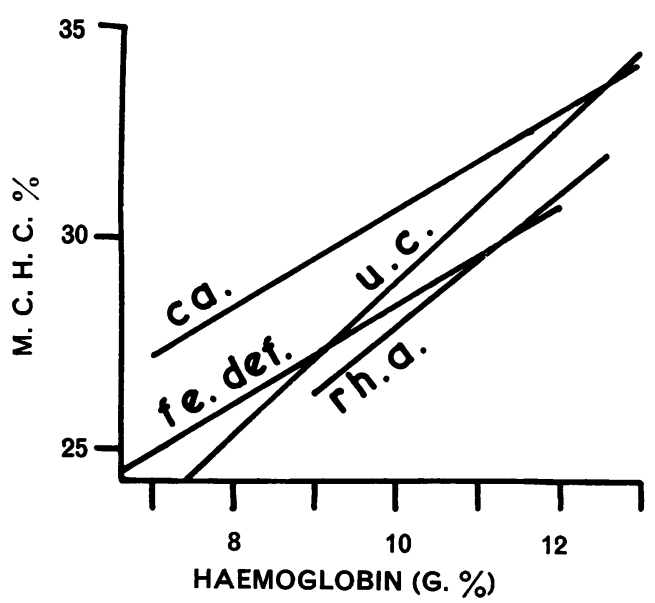

FIG. 3. Mean corpuscular haemoglobin concentration and haemoglobin in ulcerative colitis (u.c.) compared with iron deficiency (fe. def.), cancer (ca.), and rheumatoid arthritis (rh. a). References in the text. anaemia was more common in patients with a shorter total history, Pollard and his colleagues found no such relationship. In the present study anaemia did not parallel either the duration or severity of the acute exacerbation leading to admission; however, various additional factors may occur to modify the degree of anaemia, such as previous iron therapy and the amount of iron stores existing before the acute attack. The onset of symptoms may occasionally be a poor guide to the start of the disease process; a case has been reported (Ormerod and Tonkin, 1963) where histological changes preceded symptoms altogether. Also diarrhoea, although usually an early symptom, may be inconspicuous if minimal rectal changes have occurred even with advanced colonic disease.

The association between liver disease and ulcerative colitis is well known, and fatty liver, cirrhosis, pericholangitis, and cholestatic jaundice have been described. Unfortunately none of the so-called liver function tests available here are specific for liver function and other factors can cause abnormal values. The observed fall in serum albumin in males may be due to a general reflection of the severity of the disease with associated malnutrition, infection, and loss of protein from the gut rather than due to liver disease itself. A similar correlation was not found in women, perhaps because of their more delicate iron balance. Pollard and his colleagues observed that patients with lower total serum proteins or greater loss in body weight tended to be more anaemic, and Palmer, Kirsner, Goldgraber, and Fuentes (1964) also found lower albumin levels in more severely ill patients with colitis.

The mild hepatic dysfunction commonly found in colitis did not otherwise correlate with low haemoglobin levels, but additional anaemia might occur in the event of severe liver failure, as in any other type of liver disease.

Despite having no relationship to the degree of anaemia, Fig. 2 was included to stress that, although colitis symptoms often start in young adults, patients in hospital may be of any age. It was also noted that about a quarter of patients had subnormal blood urea levels, and as a final observation from the group A case reports it was wondered whether disturbances in calcium metabolism might explain the slightly elevated serum alkaline phosphatase levels found in some patients, but little work appears to have been done on this aspect so far.

The lowered serum iron levels in the group B patients (Table V) are similar to those reported by Barr, Delava, and Zetterström (1955) and Beal, Skyring, McRae, and Firkin (1963). Anaemia and hypoferraemia are found in total body iron deficiency 
and also in infections. In the latter state the T.I.B.C. tends to be lowered and iron stores present or increased; in true iron-deficiency anaemia the T.I.B.C. is raised while iron stores are scanty or absent. The distinction between the two types is of practical importance since the anaemia and low serum iron values in infection do not respond to iron therapy (Cartwright and Wintrobe, 1952).

The normal T.I.B.C. found in colitis might be explained by assuming the presence of both iron deficiency and infection. If infection were a major factor in the production of anaemia, it might be expected that those patients with the highest white blood count and erythrocyte sedimentation rate would have the greatest anaemia, but such a correlation had not been shown (Table III). To examine iron stores by routine bone marrow aspiration was considered unjustifiable in ill patients unless the result was likely to influence treatment and in only one case was it carried out. In this patient (no. 11) there was almost complete absence of stainable iron as compared to a control using the method of Douglas and Dacie (1953).

It is believed that these results confirm the widely held view that there is a definite iron-deficiency state in ulcerative colitis which overshadows any effect due solely to infection. It is hoped later to report on iron isotope studies of this group of patients and to investigate more fully the factors which might cause iron deficiency, such as colonic bleeding.

Shortening of the red cell life (Table VI) appeared to be a further mechanism to account for anaemia of sudden onset, and patient no. 25 without severe diarrhoea was typical of auto-immune haemolytic anaemia with a reticulocyte count of $40 \%$, positive Coombs test, and response to splenectomy. Serum bilirubin was normal and no Heinz bodies were seen. Patient no. 15 also had gross shortening of the red cell life, despite allowing for faecal bleeding, and her haemoglobin fell during an exacerbation of diarrhoea. The Coombs test was negative and liver function tests were normal; reticulocytes were only $1.0 \%$, perhaps because the more usual marrow response was prevented by concomitant iron deficiency as in hookworm anaemia (Layrisse, Linares, and Roche, 1965).

Four varieties of haemolytic anaemia have so far been described in colitis. Auto-immune haemolytic anaemia is recorded in women by Lorber, Schwartz, and Wasserman (1955), Balint, Hammack, and Patton (1963), and Fong, Fudenberg, and Perlmann (1963) while Edwards and Truelove (1964) describe one case in their 624 patients. Secondly, Heinz-body anaemia is reported by Spriggs, Smith, Griffith, and Truelove (1958) almost certainly due to salicylazosulphapyridine therapy. Neither patient no. 15 nor no. 25 were receiving this drug and the latter workers found no Heinz bodies in untreated cases. Thirdly, Holdsworth, Hall, Dawson, and Sherlock (1965) review colitis patients in whom biliary cirrhosis and haemolysis were associated as described in the Case Records of Massachusetts General Hospital (1954), and by Boden, Rankin, Goulston, and Morrow (1959) and Vinnik and Kern (1963); Palmer et al. (1964) also report two further patients. Details of the haemolytic episodes are, however, scanty but possibly increased red cell destruction may encourage biliary obstruction or alternatively haemolysis may be due to the cirrhosis (Keene, 1966). As the serum alkaline phosphatase level is generally greatly raised in biliary cirrhosis, it may be of interest that no correlation was found between the concentration of this enzyme and the occurrence of anaemia in group A patients (Table III). Fourthly, slight shortening of the red cell life was found in colitis by Beal et al. (1963) in patients in remission but this minimal degree of haemolysis may be rather non-specific and be associated with the equally non-specific shortening of red cell life found in iron deficiency (Rasch, Cotton, Griggs, and Harris, 1958) and several inflammatory states. Blood loss from the gut also affects the ${ }^{51} \mathrm{Cr}$ survival curve and this has been allowed for in Table VI, although the validity of Hughes Jones' (1958) correction for this is in doubt as Sheehy and Berman (1960) bled two volunteers $300 \mathrm{ml}$. each in six days and found the ${ }^{51} \mathrm{Cr}$ curve unaltered.

It is believed that a fifth type of red cell destruction may occur in ill patients with severe colitis as exemplified by patient no. 15 . Because of urgent blood transfusions or operation accurate ${ }^{51} \mathrm{Cr}$ studies are often not possible and unfortunately other patients in this series could not be studied.

Bassler (1960) stated that the sudden development of anaemia without much rectal bleeding occurred in $1 \%$ of colitis cases; he described five such patients and attributed the anaemia to 'toxic factors' without measuring the red cell life. It seems more likely, however, that these cases were similar to patient no. 15, and it is believed that this type of haemolytic anaemia occurring during an exacerbation of colitis is more common than is generally realized.

From Table $\mathrm{V}$ it appears that deficiencies of $\mathbf{B}_{12}$ are unlikely to cause anaemia, and Beal et al. (1963) found normal absorption of ${ }^{58}$ Co-labelled $B_{12}$ in three patients, although Salem, Truelove, and Richards (1964) report borderline results in 13 acute cases. Perillie and Nagler (1959) and Edwards and Truelove (1964) describe pernicious anaemia in colitis and the latter suggest that the incidence of the association of the two conditions is greater than that expected by chance. 
It also seems unlikely that folic acid deficiency contributed to the anaemia although four out of 14 patients had low serum levels. The low haemoglobin level of patient no. 3 was corrected without folic acid therapy while patient no. 17 , with the lowest level, was much undernourished and, as she had thin, friable veins and was very frightened of venepunctures, fuller investigations were avoided.

In conclusion, iron deficiency probably accounted for the anaemia in group B patients, although increased red cell destruction was shown to be an additional factor. It is later hoped to study blood loss and other possible causes of iron deficiency in greater detail.

\section{SUMMARY}

Four hundred and seventy-nine reports and an additional 28 ward patients have been studied in order to assess some aspects of the incidence and cause of anaemia in ulcerative colitis.

Anaemia was found to be commoner in women and in patients with the whole colon involved by colitis. The mean corpuscular haemoglobin concentration and the level of serum albumin both fell with the haemoglobin concentration but there was no correlation between the degree of anaemia and length of history, age of patient, white blood count, erythrocyte sedimentation rate, and so-called liver function tests.

Hypoferraemia was commonly found (as reported in other series) and reasons are given for suggesting that there is a true iron-deficiency state in colitis. Red cell survival is discussed and an additional type of case is described in which haemolysis occurred during an acute exacerbation of colitis and was not associated with sulphasalazine therapy nor autoimmune phenomena. There was no evidence that vitamin $\mathrm{B}_{12}$ deficiency contributed to the anaemia and only two out of 14 patients had serum folate levels of $2 \mathrm{~m} \mu \mathrm{g}$. $/ \mathrm{ml}$. or less.

I thank Dr. R. D. Tonkin for his advice and encouragement, and for allowing me to study cases under his care. I am also grateful to Professor M. D. Milne for his assistance and advice. For permission to study group A patients I thank the consultant staff of the Gordon Hospital, also Dr. I. P. M. MacDougall, whose follow-up records facilitated data recording, and Dr. I. M. Dawson, Dr. J. H. Wilkinson, and Dr. P. Flood for pathological, biochemical, and $x$-ray reports respectively. I also thank Mr. S. O. Aylett, Professor H. Ellis, and Mr. R. W. Raven and the late Dr. E. R. Cullinan at the Westminster and Gordon Hospitals and Dr. T. Parkinson at Luton and Dunstable Hospital for allowing their patients to be studied, Dr. T. G. Jones for much helpful advice with the haematology and for the $B_{12}$ and folate assays, Dr. J. P. Nicholson and Dr. J. S. Zilva for advice on isotope techniques and serum iron respectively, and Miss P. Kay for her typing. The expenses of this study were met by a grant from the Westminster Hospital discretionary fund and this project formed part of a thesis for the London M.D.

\section{REFERENCES}

Balint, J. A., Hammack, W. J., and Patton, T. B. (1963). Association of ulcerative colitis and red blood cells coated with autoimmune antibody. Report of a case, Amer. J. dig. Dis., 8, 537-544.

Barr, M., Delava, S., and Zetterström, R. (1955). Studies of the anemia in ulcerative colitis with special reference to the iron metabolism. Acta paediat., 44, 62-72.

Bassler, A. (1960). Acute anemia in ulcerative colitis. Amer. J. Proctol., 11, 291-295.

Beal, R. W., Skyring, A. P., McRae, J., and Firkin, B. G. (1963). The anemia of ulcerative colitis. Gastroenterology, 45, 589-603.

Beutler, E. (1959). The red cell indices in the diagnosis of iron-deficiency anemia. Ann. intern. Med., 50, 313-322.

Boden, R. W., Rankin, J. G., Goulston, S. J. M., and Morrow, W. (1959). The liver in ulcerative colitis. The significance of raised serum-alkaline-phosphatase levels. Lancet, 2, 245-248.

Bruce, D., and Cole, W. H. (1962). Complications of ulcerative colitis. Ann. Surg., 155, 768-781.

Cameron, A. D. (1960). Gastro-intestinal blood loss measured by radioactive chromium. Gut, 1, 177-182.

Cartwright, G. E., and Wintrobe, M. M. (1952). The anemia of infection. XVII. A review. Advanc. intern. Med., 5, 165-226.

Dawson, I. M. P., and Pryse-Davies, J. (1959). The development of carcinoma of the large intestine in ulcerative colitis. Brit. $J$. Surg., 47, 113-128.

Delaney, J. W. (1960). Handbook of Haematological and Blood transfusion Technique. Butterworth, London.

Douglas, A. S., and Dacie, J. V. (1953). The incidence and significance of iron-containing granules in human erythrocytes and their precursors. J. clin. Path., 6, 307-313.

Edwards, F. C., and Truelove, S. C. (1964). The course and prognosis of ulcerative colitis, Part III. Complications. Gut, 5, 1-15.

Farmer, R. G., Scudamore, H. H., and Bayrd, E. D. (1963). Comparison of clinical findings and hematologic changes in patients with chronic ulcerative colitis. Amer. J. Gastroent., 40, 601-610.

Fong, S., Fudenberg, H., and Perlmann, P. (1963). Ulcerative colitis with anti-erythrocyte antibodies. Vox Sang (Basel), 8, 668-679.

Freireich, E. J., Ross, J. F., Bayles, T. B., Emerson, C. P.. and Finch S. C. (1957). Radioactive iron metabolism and erythrocyte survival studies of the mechanism of the anemia associated with rheumatoid arthritis. J. clin. Invest., 36, 1043-1058.

Garvin, R. O., and Bargen, J. A. (1937). The hematologic picture of chronic ulcerative colitis: its relation to prognosis and treatment. Amer. J. med. Sci., 193, 744-752.

Holdsworth, C. D., Hall, E. W., Dawson, A. M., and Sherlock, S. (1965). Ulcerative colitis in chronic liver disease. Quart. J. Med., 34, 211-227.

Hughes Jones, N. C. (1958). Measurement of red-cell loss from gastrointestinal tract, using radio-active chromium. Brit. med. J., 1, 493-496.

Keene, W. R. (1966). Uncommon abnormalities of blood associated with chronic ulcerative colitis. Med. Clin. N. Amer., 50, 535-541.

Kirsner, J. B., Palmer, W. L., Maimon, S. N., and Ricketts, W. E. (1948). Clinical course of chronic nonspecific ulcerative colitis. J. Amer. med. Ass., 137, 922-928.

Layrisse, M., Linares, J., and Roche, M. (1965). Excess hemolysis in subjects with severe iron deficiency anemia associated and non-associated with hookworm infection. Blood, 25, 73-91.

Lorber, M., Schwartz, L. I., and Wasserman, L. R. (1955). Association of antibody-coated red blood cells with ulcerative colitis. Report of four cases. Amer. J. Med., 19, 887-894.

Marrack, D. (1960). Quoted by Delaney, J. W.

Massachusetts General Hospital, Case records (1954). Case 40491. New Engl. J. Med., 251, 983-988.

Miller, A., Chodos, R. B., Emerson, C. P., and Ross, J. F. (1956). Studies of the anemia and iron metabolism in cancer. J. clin. Invest., 35, 1248-1262.

Mollison, P. L., and Veall, N. (1955). The use of the isotope ${ }^{51} \mathrm{Cr}$ as a label for red cells. Brit. J. Haemat., 1, 62-74.

Ormerod, T. P., and Tonkin, R. D. (1963). Pre-symptomatic ulcerative colitis. Proc. roy. Soc. Med., 56, 288-289. 
Palmer, W. L., Kirsner, J. B., Goldgraber, M. B., and Fuentes, S. S. (1964). Disease of the liver in chronic ulcerative colitis. Amer. J. Med., 36, 856-866.

Perillie, P. E., and Nagler, R. (1959). Development of pernicious anemia in a young patient with chronic ulcerative colitis: report of a case. New Engl. J. Med., 261, 1175-1177.

Peters, T., Giovanniello, T. J., Apt, L., and Ross, J. F. (1956). A new method for the determination of serum iron binding capacity. J. Lab. clin. Med., 48, 274-279.

Platt, J, W., Schlesinger, B. E., and Benson, P. F. (1960). Ulcerative colitis in childhood. Quart. J. Med., 29, 257-277.

Pollard, H. M., Block, M., and Bachrach, W. H. (1947). Causes and management of anemia associated with chronic ulcerative colitis. J. Amer. med. Ass., 134, 341-346.

Rankin, J. G., Goulston, S. J. M., Boden, R. W., and Morrow, A. W. (1960). Fulminant ulcerative colitis. Quart. J. Med., 29, 375-390.
Rasch, C. A., Cotton, E. K., Griggs, R. C., and Harris, J. W. (1958). The survival of autotransfused $\mathrm{Cr}^{51}$-labeled erythrocytes in infants with severe iron deficiency anemia. J. Lab. clin. Med., 52, 938.

Salem, S. N., Truelove, S. C., and Richards, W. C. D. (1964). Smallintestinal and gastric changes in ulcerative colitis: a biopsy study. Brit. med. J., 1, 394-398.

Sheehy, T. W., and Berman, A. (1960). The anemia of cirrhosis. J. Lab. clin. Med., 56, 72-82.

Spriggs, A. I., Smith, R. S., Griffith, H., and Truelove, S. C. (1958). Heinz-body anaemia due to salicylazosulphapyridine. Lancet 1, 1039-1042.

Vinnik, I. E., and Kern, F., Jr. (1963). Liver disease in ulcerative colitis Arch, intern. Med., 112, 41-49.

Whitby, L. E. H., and Brittain, C. J. C. (1957). Disorders of the Blood, 8th ed. Churchill, London. 